\title{
Mechanism of Restructuring the Company As Part of Its Innovation Strategy
}

SUMMARY

Research on company restructuring mechanisms is of strategic significance for innovation and investment development. Research has improved: scholarly and methodological approaches to the formation of enterprise restructuring mechanisms reflect modern innovation and investment development in Ukraine's economy. The key elements of restructuring include: types, strategies, methods, tools and levers. As among the various organizational and financial methods of company restructuring, corporate structuring is of outstanding significance, this research focuses on this particular method. It has also been revealed that the top 5 companies with the highest innovation indices described in this paper work in the logistics, engineering, pharmaceuticals and energy sectors.

Journal of Economic Literature (JEL) codes: O3, G34, O12

Keywords: restructuring, company, integration, corporatization, innovation index

\section{INTRODUCTION}

The need to increase the efficiency of restructuring measures at the national business entities, in particular in the context of innovation and investment development of Ukrainian companies, necessitates studying the application of the most recent restructuring forms of company management in terms of the post-crisis operation of Ukrainian economic system.

The purpose of this research is to systematize the existing approaches to restructuring, and to develop methods, tools, mechanisms for the restructuring of state-owned companies in order to boost innovation and investment; to prove the effectiveness of the corporate structuring method as a restructuring form in the management system of national companies (in particular, in the context of innovation and investment development); and to substantiating the author's expectations regarding the directions of improving companies' efficiency

Oleksandra Ashcheulova, PhD in Economics, Associate Professor, National Technical University “Dnipro Polytechnic”, Kyiv, Ukraine. 


\section{Tudományos múhely}

on the basis of restructuring under modern economic conditions.

Novelty in the research. This research has improved:

- the scholarly and methodological approaches to the mechanism of enterprise restructuring, in order to reflect the modern conditions of innovation and investment development in Ukarine's economy in comparison to the prevailing approaches and the key elements of restructuring implementation, which include types, strategies, methods, tools and levers.

- As among the various organizational and financial methods of company restructuring, corporate structuring is of outstanding significance, this research focuses on this particular method.

\section{COMPANY RESTRUCTURING MECHANISMS}

Based on the definition of the term "restructuring" provided in this research, its key element is a particular mechanism (see Figure 1). In this context, one of the main elements of such a mechanism is strategic and operative restructuring. It is necessary to point out that development in the world economy, including Ukraine, should be oriented towards the strategic restructuring of national enterprises and companies. Operational restructuring can be part of a general strategy for the development of companies and their associations, because it should focus on the needs and commercial interests of the relevant corporate structure.

While making decisions on the use of strategic and operative restructuring, top managers and owners of economic entities must understand their advantages and disadvantages. The advantages of strategic restructuring include the following: influence on all spheres of company operation without any exceptions; the formation of new, more efficient organizational, management and production structures for business entities; long-term competitive advantages; synergy from implementation. At the same time, strategic restructuring has some disadvantages, in particular: the conditions of implementation; complexity; the cost of implementation; considerable demand for specialised staff, mainly top managers - often the attraction of external specialists. The benefits of operative restructuring are as follows: fast implementation; relative simplicity; targeted influence by developed restructuring measures; a relatively low cost. The negative sides of operative restructuring are: the possibility to get negative consequences due to incoherence of employees' actions; relatively weak influence of restructuring measures on the company as the whole; the complexity in priorities determination while restructuring implementation because of a considerable rate of deficit in financial resources.

The method of corporate structuring should be classified among the organizational methods of restructuring. Thus, in her research on the method of corporate structuring as a form of restructuring the business processes of integrated and other companies, Yu. Mordvytska proves that highly competitive national corporations, and their subdivisions, own enormous resources that can be channelled into innovation and investment development to improve the national economy (Mordvytska, 2016a; 2016b). The maximum potential of such a method of restructuring for the companies during all stages of their life cycles has also been identified. 
One cannot ignore the effectiveness of financial methods in the context of restructuring, such as the optimization of pricing and taxation. Yu. Mordvytska in her studies on the effectiveness of transfer pricing in companies (Mordvytska, 2016) clearly shows the relevant arguments and calculates the economic effect of the implementation of such restructuring measures.

In the context of the restructuring mechanism, special focus needs to be placed on the characterization of the company in terms of innovation and investment development of the country's economy, and on the appropriate restructuring strategies. The strategies of innovation implementation are the most important and should be adapted to the economic entities in all stages of their life cycles. The key strategies are:

- the modernization of production;

- innovative technology implementation;

- the development of new types of goods and services.

The group of strategies provided in the study allows in-depth restructuring at the company by choosing one of the ways that need more changes in order to achieve the overall objective and the set of goals during a certain stage of the company's life cycle.

Figure 1: Mechanism of company restructuring in terms of innovation and investment development of the country's economy

\begin{tabular}{|c|c|c|c|}
\hline \multicolumn{4}{|c|}{ MECHANISM OF COMPANY'S RESTRUCTURING } \\
\hline Types & \multicolumn{3}{|c|}{ Methods } \\
\hline $\begin{array}{l}\text { - Operational } \\
\text { - Strategic }\end{array}$ & \multicolumn{2}{|c|}{$\begin{array}{l}\text { Financial: } \\
\text { - method of "clearing the } \\
\text { company's balance sheet"; } \\
\text { - method of restructuring of } \\
\text { financial flows; } \\
\text { - methods of optimization of } \\
\text { pricing; } \\
\text { - methods of financial } \\
\text { improvement; } \\
\text { - set of methods for the company's } \\
\text { financial improvement. }\end{array}$} & $\begin{array}{l}\text { Organizational: } \\
\text { - methods of reorganizing assets; } \\
\text { - methods of integration, merger; } \\
\text { - method of corporate structuring; } \\
\text { - methods of restructuring of } \\
\text { business processes; } \\
\text { - writing off of the items of fixed } \\
\text { assets which are not used. }\end{array}$ \\
\hline Tools & \multicolumn{2}{|c|}{ Strategies } & Levers \\
\hline $\begin{array}{l}\text { - Merger, integration; } \\
\text { - Adjustment of assets } \\
\text { and liabilities of the } \\
\text { balance sheet; } \\
\text { - Change in the format } \\
\text { of the organization of } \\
\text { production, person- } \\
\text { nel encouragement } \\
\text { systems; } \\
\text { - Others. }\end{array}$ & \multicolumn{2}{|c|}{$\begin{array}{l}\text { - Innovation implementation stra- } \\
\text { tegies (modernization of produc- } \\
\text { tion, introduction of innovation } \\
\text { technology, development of new } \\
\text { typs of products and services); } \\
\text { - Diversification strtategies; } \\
\text { - Development strategies; } \\
\text { - Strategies for entering new } \\
\text { markets }\end{array}$} & $\begin{array}{l}\text { - Increase in profit; } \\
\text { - Increase in the company value; } \\
\text { - Optimization of taxation; } \\
\text { - Reduction of terms of working } \\
\text { cycls; } \\
\text { - Competitive advantages; } \\
\text { - Increase in the company's innova- } \\
\text { tion and investment potential. }\end{array}$ \\
\hline
\end{tabular}

Source: Edited by the author 
The characteristics of company restructuring mechanisms in terms of innovation and investment development of the country's economy and the tools that economic entities can use for their restructuring need to be studied (see Figure 1). The number and establishment of the appropriate set of tools restructuring depend on several factors, namely:

- the current phase of the company's life cycle;

- use of the appropriate type (subtype), strategy (set of strategies), method (set of methods) of restructuring;

- the specific nature of financial and operational activities;

- the peculiarities of influencing external and internal environment factors;

- the quality of the operation of state and municipal authorities in innovation and investment development in the country's economy.

In order to emphasize the priority of corporate structuring methods in company restructuring, primary attention needs to be paid such tools as takeover and integration.

During the discussion of the levers that can be used in company restructuring and the separation of structuring methods as priority for the business entities in terms of the transformation of the Ukrainian economic system, the emphasis is placed on the development and maintenance of competitive advantages and on the increase of innovation and investment potential of the company. The competitive advantages and the development and implementation of innovation based on the optimization of their investment support provide the company with the opportunity to implement effective restructuring regardless of both the particular life cycle stage it is undergoing and the influence of external and internal factors.

In general, the positive effects of restructuring are aimed at improving the key operating and financial performance of companies; financial improvement; improvement of the level of attractiveness for investors, expanding its external financing, opportunity to develop and implement innovative technologies, solutions, know-how in operational activities, etc.

A forecast and the optimization of the growth rates in the capital investments channelled into restructuring and in the volumes of financing innovation in the economy should be performed by finding the ideal method of increasing the volume of capital investments in restructuring that leads to an increase in companies' investments in innovation.

Regarding the trends related to both capital investment in company restructuring and business entities' expenditure on innovation, the significance of Spearman's rank correlation coefficient is recommended for the two trends singled out in this research. It is necessary to calculate the critical point 1 to check the zero hypothesis about the equality of the general coefficient of rank correlation at the level of significance $\alpha$ to zero.

$$
\mathrm{T}_{\mathrm{kp}}=2.776 \sqrt{\frac{1-0.77^{2}}{6-2}}=0.88
$$

As the coefficient shows a significant correlation of 0.88 , it can be argued that there is a close correlation between investments and innovation. It should be noted that in order to find the ideal point of the ratio of investments in the restructuring and innovation of companies, it is 
necessary to identify the optimal conditions of the equations:

$$
\begin{aligned}
& \mathrm{X}_{1}-2 \mathrm{X}_{2}=100000 \\
& \mathrm{X}_{1}+5 \mathrm{X}_{2}=500000
\end{aligned}
$$

where $\mathrm{X}_{1}$ - companies' capital investments; $\mathrm{X}_{2}$ - innovation.

The original problem turns into a maximization problem:

$$
\begin{aligned}
& \mathrm{L} 1=-\mathrm{x} 1+2 \mathrm{x} 2-5=\max \\
& \mathrm{L} 2=\mathrm{x} 1+5 \mathrm{x} 2+5=\max \\
& \mathrm{x} 1-2 \mathrm{x} 2 \leq 247894, \\
& \mathrm{x} 1 \geq 0, \\
& \mathrm{x} 2 \geq 0,
\end{aligned}
$$

In order to build the feasible region, the relevant values $\mathrm{x} 1, \mathrm{x} 2$ are found from the system of linear equations: $\mathrm{X}_{1}=214,285.8$ ths. UAH. $\mathrm{X}_{2}=57,142.8$ ths. UAH.

A large part of investments in the category "Vehicles and equipment" is due to the growing number of logistics companies in Ukraine due to the active creation of the national market of logistics services and, in this context, the need for the modernization of terminals and other vehicles, including the warehouse and trade infrastructure used by the relevant companies and enterprises in the process of their economic activity. Figure 2 shows the results of an analysis of the dynamics of capital investments by types of assets for 2010-2017.

The results of the statistical analysis indicate that based on the fact that most of the investments are made at the expense of companies' and organisations' own funds (most of which are part of the corporate structures of integration), it can be concluded that the directions and magnitude of the investment injection are currently being set by the owners of international corporations, with Ukrainian companies included as their part. The obtained data also suggests that innovation is financed mainly at the expense of companies' own funds. In general, the share of companies engaged in innovation in the period between 2013-2017 is rather small - ranging between $16.1 \%$ measured in 2015 (the minimum value) and $17.3-17.7 \%$ (measured in 2013 and 2017, respectively), which indicates the need to encourage innovation in national companies owned by the state.

Figure 2: Growth rates in capital investments in company restructuring assets types between 2010-2017(\%)

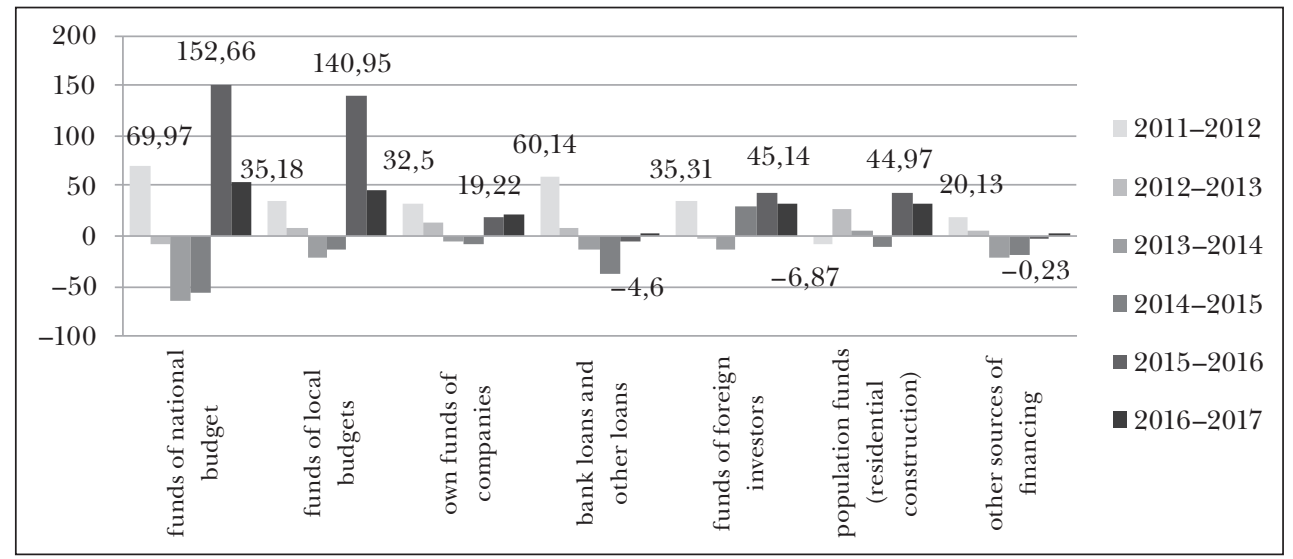

Source: The author's calculations based on data from the State Statistics Service of Ukraine, 2018 
According to the results of the survey of the Forbes expert pool, in the ranking of innovative Ukrainian companies, with respondents from the Kyiv-Mohyla Business School, the SP Advisors investment company, the IBI-Rating ranking agency, the Integrites law firm, and KPMG as a representative of the 'big four', according to the level of uniqueness of products and business processes of companies, the most comprehensive complex assessment of the scale of product, marketing and managerial innovation taking into account the level of competitive advantage was received by PrivatBank, Yuzhmash, Nova Poshta (Forbes Ukraine, 2016).

\section{INDICES OF INNOVATION DEVELOPMENT IN UKRAINIAN COMPANIES}

Forbes analysed the indicators of innovation development at the leading Ukrainian companies which actively implemented and funded innovation according to the ranking list provided by the publication. The sample of these indicators included: the costs of innovation activities
(I_in_a); the costs of creating an innovative product (I_ in_ pr); R\&D expenses $\left(I_{R \& D}\right)$; the investment costs of innovation financing (I _ fin _in); and the costs associated with professional development and training of workers (Itrain, Innovation development of the enterprise, 2016). This also applies to the identification of types and directions of the innovation development of national companies, which are also determined according to the needs of integrated companies in virtually all branches of the economy (see Figure 3).

In order to improve the reliability of the findings obtained from the analysis of innovation development in leading Ukrainian companies, weighted average values were used in the calculation of the index of innovation development, taking into account the weighting factors for each indicator. The expert estimation method is used to calculate the index of innovation development - formula 5 (see Figure 4 ), where $n_{i}$ are indices of significance for the following factors of the innovation development index (calculated

Figure 3: Distribution of innovation financing resources, 2012-2017

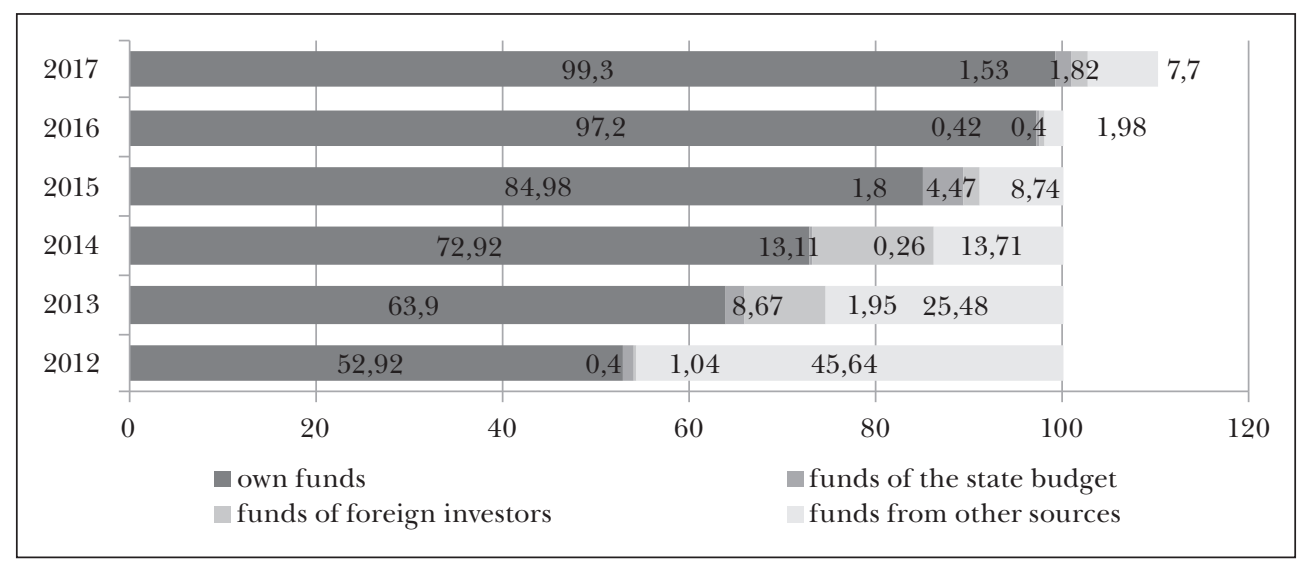

Source: The author's calculations based on data from the State Statistics Service of Ukraine, 2018 
Figure 4

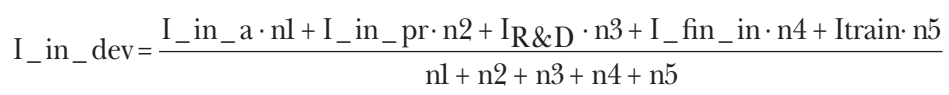

using the expert estimation method): $\mathrm{n}_{1}$ (expenditures directed to the innovation activity) $=0.25 ; \mathrm{n}_{2}$ (expenditures used to create an innovative product $)=0.18 ; \mathrm{n}_{3}$ $(\mathrm{R} \& \mathrm{D}$ expenditures $)=0.15 ; \mathrm{n}_{4}$ (investment expenditures on financing innovative activity) $=0.25 ; \mathrm{n}_{5}$ (expenditures related to the employee's professional development and training) $=0.17$ (innovation development of the enterprise, 2016).

Discussion. The indices of innovation development at Ukrainian companies and their associated businesses confirm the type of capital investments already introduced in the current research - logistic and agrarian companies. It seems that the companies that are parts of clusters of companies with the highest rate of innovation development belong to the corresponding corporate entities - groups that have a broad range of opportunities for innovation and that are able to accumulate a significant investment capital based on the consolidation of all types of corporate resources. This confirms the effectiveness of the new form of company restructuring - corporatization, which has the highest potential in the period of improving the national economy, and in particular in the innovation and investment context.

\section{Conclusions}

The results of the study have identified that under the modern conditions of in- novation and investment development in the Ukrainian economy, the key element is increase in the efficiency of restructuring both on macro-economic and on micro-economic levels, including the privatization of companies in government and municipal ownership. Based on a critical study of the papers of Ukrainian and foreign scholars, this study has identified the essence of the term "restructuring". It has also provided characteristic features of the overall objective and a set of goals within the restructuring of business entities, which undergo different stages during their life cycles (generation, growth, stability and decline). A company restructuring mechanism has been developed separately under the modern conditions of innovation and investment development in the country's economy. In addition, this research has also identified the characteristics of its components: the corporate restructuring method; the strategies of introducing innovation and diversification; the restructuring tools of takeover and integration; the levers of restructuring that are connected with the creation of competitive advantages and the increase of innovation and investment potentials for the company.

The study has also revealed that the directions of innovation and investment development in the national economy focus on the needs and interests of the owners of large international corporate entities - holdings and groups that direct the largest amount of investment 


\section{Tudományos múhely}

inflows into the activities of Ukrainian companies, in particular, into innovation development. It is proven that the results of the evaluation of the level of innovation development in companies by the indexation method enable us to predict trends in company innovation development. The sectors of the national economy that actively implement innovation and invest in innovation development are finance, logistics, pharmaceuticals, mechanical engineering and the new Ukrainian market - e-commerce. The companies of these industries have the highest indicators of innovation development and, accordingly, the prospects of development in the relevant markets in the years to come.

Further studies should focus on disclosing the problems of Ukrainian company restructuring, especially on the integration of the Ukrainian economy into the common European Economic Area.

\section{REFERENCES}

Amsden, Alice - Kochanowicz, Jacek - Taylor, Lance (1994): The Market Meets Its Match. Restructuring the Economies of Eastern Europe. Harvard University Press.

Arafiev, S. O. (2014): Enterprise Restructuring: Approaches, Essence, and Components. Manager, No. 2, 129-134.

Carlin, Wendy - Mayer, Colin - Sinn, Hans-Werner - Grilli, Vittorio (1992): Restructuring Enterprises in Eastern Europe. Economic Policy, Vol. 7, No. 15, 346-348, https://doi. org/10.2307/1344545.

Charap, Joshua - Zemplinerova, Alena (1993): Restructuring in the Czech Economy. Working Paper No. 2, European Bank for Reconstruction and Development, London.

Commander, Simon (1998): Enterprise Restructuring and Unemployment in Models of Transition. The World Bank, Washington, https://doi. org/10.1596/0-8213-4168-5.
Djankov, Simeon - Murrell, Peter (2002): Enterprise Restructuring in Transition: A Quantitative Survey. Journal of Economic Literature, Vol. 40, No. 3, 739-792, https://doi. org/10.1257/002205102760273788.

DTEK Holding (2016): About DTEK Group. www. dtek.com/uk/home.

Filimonenkov, O. S. (2002): Finance of Companies. Kondor, Kyiv.

Forbes Ukraine (2016): Save the Future: The First Rating of Innovative Companies in Ukraine. http:/ / forbes.net.ua.

Goldberg, Itzhak - Watkins, Alfred (2000): Enterprise Restructuring. The World Bank, Washington.

Hoekman, Bernard M. - Pohl, Gerhard (1995): Enterprise Restructuring in Eastern Europe: How Much? How Fast? Where? Preliminary Evidence from Trade Data. World Bank Publications, Washington, https://doi.org/10.1596/18139450-1433.

Innovation Development of the Enterprise (2016): Methods of Evaluation of Innovation Development of Enterprise for Five Indicators. http:/ / pidruchniki.com/85846/ekonomika/metodika_otsinyuvannya_rivnya_innovatsiynogo_rozvitku_pidpriyemstva_pyatma_pokaznikami.

Kostiunik, O. V. - Nakonechna, A. A. (2016): Main Reasons and Peculiarities of Implementation of Ukrainian Enterprises Restructuring. Scientific Journal of Kherson State University: Economics, No. 17, 143-146.

Montes-Negret, Fernando - Papi, Luca (1997): The Polish Experience in Bank and Enterprise Restructuring. MOST: Economic Policy in Transitional Economies, Vol. 7, No. 1, 79-104.

Mordvytska, Yu. S. (2016a): Transfer Pricing in the Management of Corporate Logistics Business Processes. Unyversytetskaja nauka-2016, No. 3, 92-93.

Mordvytska, Yu. S. (2016b): The Functional Approach to Improving the System of Logistics Business Processes Integrated Holdings. Teoretychni i praktychniaspekty ekonomiky ta intelektualnoji vlasnosti, No. 1, 61-65.

Nova poshta (2016): Business Clients. https://novaposhta.ua/ru.

Prushkivskyi, V. G. (2008): Restructuring of Industry in the Region: the Theory, Methodology, Practice. Problemi ekonomiki promislovih regioniv, Harkiv. 


\section{Tudományos múhely}

Regulations on the Procedure of Restructuring of Enterprises (2002): Ofitsiyny visnyk Ukrainy, No. 19

Samonis, Val (ed.) (1998): Enterprise Restructuring and Foreign Investment in the Transforming East. The Impact of Privatization. Routledge, London.

Santarek, Krzysztof (2011): Enterprise Restructuring and Improvement. AIM 2011 Conference, Skopje, www.europe-aim.eu/wp-content/ uploads /2012/07/Santarek-2011-SkopjeK.S.-2011_09_23.pdf.

Savruk, O. I. (2010): Models and Methods of Restructuring Companies in a Market Economy. Kyyivskyy natsional'ny yekonomichnyy un-t, Kyiv.

SCM Group (2016): Strategic Management. www.scmholding.com.

SSSU (2018a): Capital Investment Based on Types of Assets. State Statistics Service of Ukraine, www. ukrstat.gov.ua.
SSSU (2018b): Sources of Innovation Activity Financing. State Statistics Service of Ukraine, www. ukrstat.gov.ua.

SSSU (2018c): Net Profit (Loss) of Enterprises Based on Types of Economic Activity. State Statistics Service of Ukraine, www.ukrstat.gov.ua.

SSSU (2018d): The Number of Legal Entities Based on Organizational Forms. State Statistics Service of Ukraine, www.ukrstat.gov.ua.

Stojčić, Nebojsa (2012): Patterns and Determinants of Enterprise Restructuring in Central and East European Countries. Ekonomska misao $i$ praksa, Vol. 7, No. 2, 429-456.

Tereshchenko, O. O. - Voloshaniuk, N. V. (2009): Financial Dominants of Enterprises Restructuring. Financy Ukrainy, No. 4, 82-90.

Viatrovych, O. (2011): Restructuring as One of the Most Important Ways to Provide Enterprise Activity. Economist, Vol. 7, No. 297, 40-42. 